\title{
Geopolitical Manifestations of Globalization Subjects
}

\author{
Ivan A. Pfanenshtil* \\ Siberian Federal University \\ 79 Svobodny, Krasnoyarsk, 660041, Russia
}

Received 15.12.2014, received in revised form 14.01.2015, accepted 20.04.2015

\begin{abstract}
The paper focuses on the problem of globalization in the context of geopolitics. The author explores features of geopolitical space transformation under the modern conditions of globalization processes. Particular attention is paid to the analysis of the "new world order", claimed by the subjects of globalization. The author proves that the unipolar government of the world is not optimal, as it implies multiplication of disasters and suffering to many nations.
\end{abstract}

Keywords: unipolar world, geopolitical space, "new world order", "universal values ", national values, world leadership.

Research area: philosophy.

Globalization and the new world order (in fact, the division of the world and the struggle for world domination), shrouded in myths of "universal values ", "liberal and democratic pluralism", bring and have already brought new injustices under the rule of force in the political issues.

Total in its character aggressiveness of the new world order and the Americanization processes are aimed at the destruction of anybody confronting this in the zone of "vital US interests". These "zones of vital interests", oddly enough, are in the areas specified in the German geo-strategy of the "new world order": the Persian Gulf, Afghanistan, Iraq, East Asia, Ukraine, the Caucasus, Georgia, Kyrgyzstan, and so on.

The "new world order" does not tolerate objections from weak states, and therefore, the choice of scenarios for the future is very limited and is being sharply reduced as the productive forces and the country's defense system decay: "Following the loss of Russia of its intercontinental missiles with nuclear warheads, with maintaining other trends and motivations, the country will become a "perfect enemy" to superpower, the enemy, which regardless of its interests and behavior, will face the fate of the current Yugoslavia"... Thus, Russia, while fostering the basic tendencies of world and domestic development, with high probability will be the object of military aggression from the US and other NATO countries. But this aggression is bound to appear for their internal reasons that are not likely to be associated directly with Russia [Kalashnikov, p. 36-37].

(C) Siberian Federal University. All rights reserved

* Corresponding author E-mail address: ndubrovskaya@sfu-kras.ru 
After the collapse of Russia and the emergence of a unipolar world the United States began to turn into a completely different country over the past decade.

In fact, at the present time, NATO and the United States are increasingly turning into an international gendarme, ensuring the interests of transnational capital and the global oligarchy. Modern ideologists of the new world order consistently demonstrate aggressiveness and desire for the destruction of government institutions, and they do not leave Russia and most other countries any hope of forming and carrying out an independent policy in the national interest. Realizing its dominant position in the institutions of the US government, the world oligarchy is trying to use the national resources of the country to ensure its global domination. That is why the ideologists of the world oligarchy committed to maintaining US global leadership.

US national security strategy in the $21^{\text {st }}$ century is fastened upon keeping world leadership. This strategy outlines clearly the basic features of the new world order. Expanding the "zone of vital US interests" to the scale of the entire planet, and the content of those interests - to the control of natural, demographic and economic resources of other countries, at the same time establishing an exclusive monopoly on the use of force in international affairs for the American military and diplomatic mechanisms, the world oligarchy plans to ensure its dominant position in the $21^{\text {st }}$ century. "The responsibilities of the national security of the United States are actually declared as to provide the global control of the world oligarchy in important matters of serving the interests of transnational capital, including easy access to the resources of other countries, together with their natural and human resources, access to their markets, elimination of any national barriers to national capital transfer and reproduction. At the same time US national security is to control over the population, pollution, and political systems in other countries [Glaz'ev, p. 133]

In order to harmonize the interests of the global oligarchy and the national interests of the most developed countries there has been developed a racist theory of the "golden billion", according to which the perfect existence on the planet can be guaranteed only to 1 billion people of the most prosperous countries, while the other countries will endure the miserable fate of raw materials appendage and supplier of cheap human material to serve the interests of transnational capital. This doctrine is not at all speculative; it is already applied in practice in the management of international relations. Thus, those countries, identified as the elected ones, are allowed to protect the internal market, to lead an aggressive export policy, to support their producers, to maintain their national culture and public morality, to impose their interests to others, including the use of armed force. And other players should follow blindly the recommendations of international organizations, which represent the interests of the global oligarchy, and try not to impede access to their markets for transnational capital, while in their cultural space they are asked to introduce stupefying and corrupting the public technologies of national culture and public morality destruction.

Analyzing the views of Western scholars, one can conclude that, despite the deep and true comments on the process of globalization and the new world order, they tend to favor a reconstruction of traditional structures of mondialism, not noticing the fundamental role of the international financial oligarchy, which in fact, controls these structures. However, we should not forget that globalization is not the element that falls upon us like an earthquake, but rather the chain of decisions involving certain people and structures. Therefore, globalization cannot be socially neutral and impersonal. There 
are actors, organizers and creators of this process, the objects of which are countries to experience this process and to be likely to become the victims of globalization, bearing its costs. Therefore, the problem is not in the process of globalization, but in its realization and in the interests which it pursues.

Despite the apparent amorphous character and uncertainty of what is here called the world oligarchy, in practice all its links act consistently, which is surprising because of the objective convergence of interests, as well as the existing long-term kinship, family, national, compatriot, and clan ties. They make up the rules, their own language, influence technology, organizational structure and communication. However, one should not exaggerate and reduce this tendency to conventional scheme of world imperialism or Masonic conspiracy. The determinants here are objective economic interests, organizing major international capital in order to implement policies favorable to it. As this capital is active within the global market, so politics, which this capital seeks to execute, has global nature. In the early stages the transnational capital grows out of mediation in international trade and financial sectors. In real today's economy the capital surplus is concentrated in transnational corporations that lobby this very globalization of world economic development. The transnational corporations are investing capital in the resource base of the underdeveloped countries not only in order to obtain cheap raw materials, but also to acquire control over the resource base, so they prevent the formation of the technology process chain, i.e. creation of industrial enterprises, which are needed to produce the final product directly on the territory of the recipient countries. Thus, the slogan of an open market competition becomes the means of fixing monopolies. Moreover, having become the owners of the resource base, the transnational corporations are able to control the volume of extracted raw materials on their own, being guided by market conditions, rather than the interests of the underdeveloped countries.

One of the especially powerful incentives to the development of transnational capital, concentrated in the hands of the financial oligarchy, is international, and later the world wars, which dramatically increase the demand for government loans and create opportunities to gain super profit. Providing loans to all battling parties, the financial oligarchy is always a winner, which participates in the regular redivision of the world, at the same time receiving indemnity from the losers and interest from the winners. In contrast to the interests of the peoples and countries the world oligarchy is not afraid of war and global destabilization. If for any nation the war is primarily human victims, and for any states the war brings huge material losses and a threat to national security, for the transnational capital the war has always been the source of super profits and easy meat. It is no accident and quite natural that the main argument of the current ideologists of globalization as a world Americanization is the US war power. That is why the military force as a policy argument again comes to the foreground, as it favors the world oligarchy dreaming of the redivision of the world and the new world order in the $21^{\text {st }}$ century.

"Every universalist appeal to justify enforced interference in the sovereign rights of another state is simply, according to generally accepted position, a cover for private interests of an aggressor who uses an unfair argument, blaming their opponents" [Khabermas, p. 19]. But this is the reality of the liberal and democratic globalization.

In modern conditions we still observe a dangerous process of youth consciousness manipulation and entrenchment of alien "cultural values". The millennial culture of Russia, its folk traditions and morals, great literature and 
language are openly and deliberately neglected and destroyed. There are activities aimed at damaging the Russian language, literature, all the history and culture of the great millennial state, its people, the great Orthodox teachers, and its great civilizational role are belittled and sometimes distorted beyond recognition. In addition, in Russia by the beginning of the $21^{\text {st }}$ century there were completely destroyed industrial, agricultural and scientific centers, hundreds of thousands of young professionals and scientists have had nothing but to seek a better future in the West. If we add to this "picture" billions of dollars in debt, made by the Government of reformers, uninterrupted export of currency, lack of investment, which has been promised many times, and the worst thing $\square$ the deterioration of public morals and distrust in the government, then the situation is very complicated. But in our opinion, it is not pessimistic. In Russia, there have been even more difficult times (during intervention, capture of Moscow, wars, and so on.), however, these periods have not been so vile, and every time the Russian people found the strength and their own way to a revival. The people survived and revived, when they and their leaders have followed their natural, seasoned in climatic and historical conditions, specific social, dominant character of communal unity, mutual aid (rather than individualism), the non-possessors attitude (rather than consumerism), sacrifice (rather than selfishness), truth (rather than right), i.e. harmony and perfection of human relations, which are the basis of the collectivist type of society. On the contrary, there is every reason to believe that the deviations from the natural social dominance and the collectivist type of society generate current social, political, economic and moral problems of Russian society.

The history has repeatedly denied futile attempts to "copy" the Western way of culture and ideology in Russia, and every time these attempts have been doomed to failure, having brought untold suffering to the Russian people. The fact that domestic and foreign ideological culture are incompatible and fundamentally different from each other because they belong to different types of society, which could not be understood by philosophical and Marxist ignorant people and would-be reformers.

The idea of self-identity of peoples and cultures are well represented in the works of geopolitics-Neo-Eurasians in particular. According to A. Dugin, the vast majority of Eurasian states and peoples have their continental, "land" specifics of national history, state traditions, economic ethics. They see the American political and strategic influence as an unbearable burden, alienating their nations from their historical destiny. In the current geopolitical situation, the question of choice is extremely acute, we will either have the "new world order" under the leadership of the United States, where all nations and peoples will be impersonal and obedient "cogs" in the mondialist technocratic, atheistic-mercantile model, or the immediate establishment of geopolitical opposition and organization of settled peoples and established states in an alternative block or multiple blocks. "Today, all responsible people should understand that the adoption of the mondialist model is neither more nor less than the complete and final destruction of the specific identity, self-identity of the historical character of their states and nations, the end of their national history" [Dugin, p. 438]. Since the future is inextricably linked with the past, the subjects of globalization often use history to form the corresponding ideology that seeks to justify the artificial pressure of globalization ${ }^{1}$.

The great German philosopher Oswald Spengler correctly predicted "The Decline of the West", which is confirmed by the works of L.N. Gumilev and modern Neo-Eurasians, 
namely A. Dugin and others. The western civilization is in the last stage of the descending ethnogenesis - the stage of obscuration (the term of L.N. Gumilev), which is expressed in an attempt to escape via the implementation of the "new world order". "Power interpretation of the history is increasingly used by the globalization ideologists just to ignore the fact that the process of cultural identification supports the complex organization of the culture subject, formed at the intersection of many values, both coming from the past and looking forward into the future, and also formed in the consistency of mental, philosophical, behavioral worldviews and landmark, national, class, professional, individual orientations"1.

1 Iatsenko, M.P. (2010). Globalizatsiia kak forma istoricheskogo protsessa i aksiologiia istorii [Globalization as a form of historical process and axiology in history]. Nauchnye problemy gumanitarnykh issledovanii (Scientific Problems of Humanitarian Studies), 9. P. 232.

2 Iatsenko, M.P. (2009). Globalizatsiia kak forma organizatsii istoricheskogo protsessa [Globalization as a form of historical process organization]. IZVESTIA: Herzen University Journal of Humanities and Sciences, 111. P. 105.

\section{References}

1. Glaz'ev, S.Iu. The genocide. M.: Terra, 1998, 320 p.

2. Dugin, A. Osnovy geopolitiki. Geopoliticheskoe budushchee Rossii [Foundations of geopolitics. Geopolitical future of Russia]. M.: Arktogeia, 1997, 607 p.

3. Kalashnikov, M. Bitva za nebesa [Battle for the skies]. M., LLC “AST Publishing House", $2002,704 \mathrm{p}$.

4. Khabermas, Iu. (2003). Diskussiia o proshlom i budushchem mezhdunarodnogo prava. Perekhod ot natsional'noi k postnatsional'noi strukture [The discussion about the past and the future of international law. The transition from the national to the post-national structure]. Bulletin of the Russian Philosophical Society, 3.

\section{Геополитические проявления \\ субъектов глобализации}

И.А. Пфаненштиль

Сибирский федеральный университет Россия, 660041, Красноярск, пр. Свободный, 79

\footnotetext{
В статье рассматривается проблема глобализации в контексте геополитики. Автор исследует особенности трансформации геополитического пространства в условиях протекания глобализационных процессов современности. Особое внимание уделяется анализу «нового мирового порядка», на который претендуют субъекты глобализаиии. Автор доказывает, что управление миром на базе однополярности не является оптимальным, поскольку несет в себе умножение бедствий и страданий многим народам.
}

Ключевые слова: однополярный мир, геополитическое пространство, «новый мировой порядок», «общечеловеческие ценности», национальные ценности, мировое лидерство.

Научная спеииальность: 09.00.00 - философские науки. 